\title{
A case of multitrauma with vena cava inferior isthmus injury
}

Selman Yeniocak*, Sunay Yıldırım*, Adem Az*,Ahmet Demirel**, Muhammed Furkan Özden*, Özlem Uzun***

* University of Health Sciences, Haseki Training and Research Hospital, Emergency Department, Istanbul, Turkey.

** University of Health Sciences, Okmeydanı Training and Research Hospital, Emergency Department, Istanbul, Turkey.

*** University of Health Sciences, Bağcılar Training and Research Hospital, Emergency Department, Istanbul, Turkey.

doi.org/10.33706/jemcr.516924

\begin{abstract}
Introduction: Introduction: Large vessel and cardiac injuries may also be seen in high-energy blunt traumas such as traffic accidents. This report describes a multitrauma patient with vena cava isthmus inferior injury brought to the emergency department following high-energy blunt trauma.

Case Report: A 33-year-old woman was brought to the emergency department following an invehicle traffic accident. On arrival, her general condition was poor, and she was unconscious and hemodynamically unstable. Physical examination revealed that the left hemithorax was enlarged compared to the right, was distorted, and did not contribute equally to respiration. Injury to the isthmus of the vena cava inferior and bleeding in the pericardial cavity were observed in addition to abdominal injury symptoms at thoracoabdominal computerized tomography. The patient was taken for abdominal surgery. After surgical intervention, she was transferred to the intensive care unit.
\end{abstract}

Conclusion: It should not be forgotten that major vascular and cardiac injuries such as vena cava inferior isthmus injury may also accompany other systemic injuries in patients subjected to highenergy trauma.

Keywords: vena cava inferior injury, $\mathrm{VCl}$,blunt chest trauma

\section{Introduction}

Traffic accidents are a significant cause of mortality in many countries, and are the problem with the highest liabilities in terms of injuries, disabilities, and workforce and other economic costs $(1,2)$. In addition to large vessel injuries in such high-energy traumas, injuries may also occur in coronary anatomical structures due to high pressure occurring around the heart $(3,4)$. This report describes a multitrauma patient brought to the emergency department following highenergy blunt trauma with vena cava inferior ( $\mathrm{VCl})$ isthmus and pericardial injury, in the light of the current literature.

\section{Case Report}

A 33-year-old woman was brought to the emergency department following an invehicle traffic accident. On arrival, her general condition was poor, and she was unconscious. Arterial blood pressure was 
$50 / 30 \mathrm{mmHg}$, heart rate was $130 / \mathrm{min}$, and respiration was superficial and was supported by an Ambu airway. Oxygen $\left(\mathrm{O}_{2}\right)$ saturation was $80 \%$. We learned from history taken from witnesses and the ambulance team that the accident had taken place with the vehicle travelling at high speed and the patient driving, that she was not wearing a safety belt, and that the air cushion failed to open during the incident. The patient's Glasgow coma score (GCS) was 6 (E1,V2,M3), and sinus tachycardia was present at electrocardiography (ECG). At physical examination, the left hemithorax was enlarged compared to the right, bilateral pulmonary respiratory sounds had decreased, more on the left, and intestinal sounds were hypoactive. The patient was placed under monitoring, and started on intravenous (iv) fluid therapy with orotracheal intubated. No pathology was determined at rectal and vaginal palpation, and the patient was attached to a portable mechanical ventilator. A Foley catheter was installed, and no hematuria was observed. No cranial injury was present, but thoracic computerized tomography $(\mathrm{CT})$ revealed bleeding, $1.7 \mathrm{~cm}$ in size, in the pericardial cavity and reduced aortic calibration secondary to hypovolemia. Bilateral diffuse pulmonary contusion, bilateral pneumothorax, more pronounced on the left, air collections in the superior mediastinum, diffuse subcutaneous emphysema in the neck, back and left thoracic wall, a depressed linear fracture in the left scapula, and multiple rib fractures in the left hemothorax were observed. Abdominal CT revealed periportal edema around the branches of the portal vein, minimal laceration to the upper pole of the left kidney, free fluid in the left retroperitoneal area extending from the upper pole of the kidney to the level of the hilus, bleeding $10 \times 7 \times 3 \mathrm{~cm}$ in size in the anterior psoas muscle in the right retroperitoneal area, and minimal free fluid in the perihepatic and perisplenic area and the pelvis (Figure 1).

\section{Discussion}

Laceration was observed in the isthmus of the $\mathrm{VCl}$ in addition to thoracoabdominal injuries. Injury to the vena cava, one of the large intrathoracic vessels, is rare due to the short neck of the vessel inside the thorax $(5,6)$. Our case was still rarer because of the accompanying cardiac injury in the form of pericardial laceration.

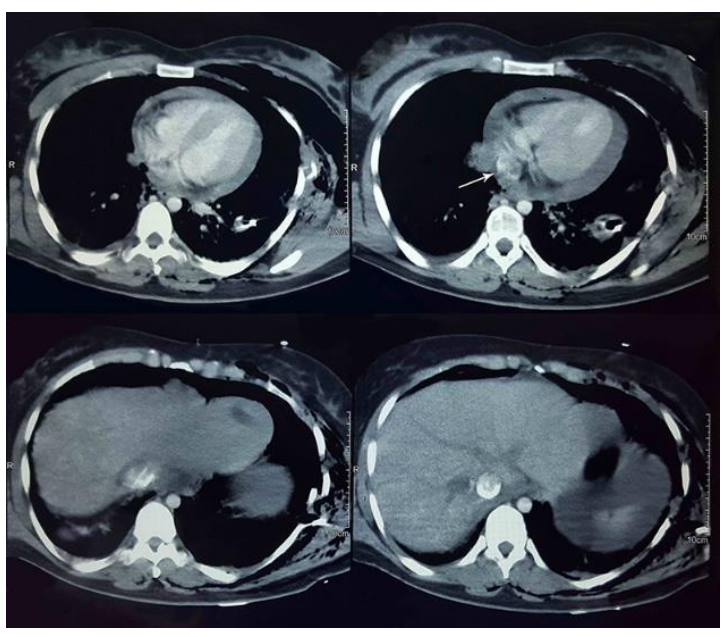

FIGURE 1. VCl isthmus injury caused by pericardial tamponade.

The patient was taken for emergency surgery, after which she was transferred to the intensive care unit for observation and treatment.

Traffic accidents occupy an important place among trauma cases presenting to the emergency department in terms of their frequency and nature. Vascular injuries associated with blunt trauma depend on the manner in which the accident occurred and the size of the kinetic force arising during it. The majority of accidents leading to injuries in the thoracic, carotid, and abdominal arteries via blunt trauma are also accompanied by severe brain, liver, lung, and pelvic injuries. Mortality is high in $\mathrm{VCl}$ injuries, and treatment is difficult, due to bleeding and other intra-abdominal injuries that generally accompany them $(7,8)$. We also determined accompanying thoracic and intra-abdominal injuries in addition to cardiovascular insult, but no cerebral, hepatic, or pelvic injury. Intrathoracic major vascular injury is frequently encountered in patients with first rib, sternum, and scapula fractures in blunt injury and thought to be exposed to 
greater kinetic energy. We observed multiple rib fractures in the left hemithorax and left scapula fracture, but no sternum fracture (8).

Safety belts are useful in terms of minimizing the severity of injuries in traffic accidents. The reported risk of death among drivers and front seat passengers in traffic accidents in which safety belts are worn is $40-50 \%$, while the risk of death among rear seat passengers is reduced by $25 \%$ (9). Another study emphasized the importance of wearing safety belts in the prevention of blunt cardiac injuries caused by traffic accidents (10). We learned from eye witnesses that the patient, who was driving, had not been wearing a safety belt at the time of the accident, and that her air cushion had not inflated.

Cardiac injuries in blunt traumas are rare, and may take the form of simple myocardial infusion or severe damage to intracardiac structures. The most common cardiac injury is myocardial contusion. Due to its relatively thin wall, the atrium is the most vulnerable part of the heart in intracardiac injuries. In terms of the valves, aortic valve injury is frequently seen $(11,12)$. We observed cardiac injury in the area of the VCI isthmus in the form of pericardial laceration, and bleeding from there into the subpericardial region. The fact that thoracic large vessel injuries are frequently encountered and the short survival time after trauma mean that speed and a systematic approach are essential during diagnosis and treatment (13).

\section{Conclusion:}

Cardiac injuries and injuries to major vessels such as the isthmus of the $\mathrm{VCl}$ may also be seen in patients exposed to high-energy blunt trauma. Major vascular injury should therefore be considered in the event of vital sign abnormality in unconscious patients presenting to the emergency department, and advanced imaging and trauma monitoring should be performed.

\section{References:}

1.Büyük $Y$, Üzün İ, Erkol Z, Ağrıtmış $H$, Üstündağ KT. Air bag-mediated fatal craniocervical trauma: a case report. Ulus Travma Acil Cerrahi Derg 2010; 16: 379-81.

2. Sümer N. Trafik kazalarında sosyal psikolojik etmenler: Sürücü davranışları, becerileri ve sosyal politik çevre. Türk psikoloji yazıları, Ankara 2002; 5(9-10); 1-14

3. Alaçayır i, Köksoy C. Periferik DamarYaralanmaları. Ertekin C, Taviloğlu K, Güloğlu R, Kurtoğlu M editors. Travma Kitabı. İstanbul, 2005. p.1197-213.

4. Velmahos GC, Karaiskakis $M$, Salim A, Toutouzas KG, Murray J, Asensio J, et al. Normal electrocardiography and serum troponin I levels preclude the presence of clinically significant blunt cardiac injury. J Trauma 2003; 54: 45-50

5. Lam Bk, Pettersson GB, Vogt DP. Urgent inferior vena cava replacement with an autologous pericardium tube graft. J Thorac Cardiovasc Surg 2003; 126: 2101-3.

6. Gloviczki P, Pairolero PC, Toomey BJ, Bower TC, Rooke TW, Stanson AW, et al. Reconstruction of large veins for nonmalignant venous occlusive disease. J Vasc Surg 1992;16: 750-61.

7. İnan B, Aydın Ü, Erkalp K, Yaşar T, Başel H. Vena cava inferior yaralanmalarında cerrahi yaklaşım. Türk Göğüs Kalp Damar Cer Derg 2011; 19: 366-70.

8. Özbudak E, Arıkan AA, Yavuz S. Toraks travmalarında vasküler yaralanmalara genel bakış. Yücel $O$, editör. Toraks Travmaları ve Tedavisi. Ankara, 2013. p.186-203.

9. McCartt AT, Ribner SA, Pack AI, Hammer MC. The scope and nature of the drowsy driving problem in NewYork state. Accid Anal Prev 1996; 28: 511-7. 
10. Kutsukata N, Sakamoto Y, Mashiko K, Ochi M. Morphological evaluation of areas of damage in blunt cardiac injury and investigation of traffic accident research. Gen Thorac Cardiovasc Surg 2012; 60(1): 31-5

11. Gucuk Ipek E. Posttraumatic tricuspid valve injury and severe tricuspid valve regurgitation. Ulus Travma Acil Cerrahi Derg 2013;19(5): 4724.

12. Unal M, Demirsoy E, Gogus A, Arbatli H, Hamzaoglu A, Sonmez B. Acute aortic valve regurgitation secondary to blunt chest trauma, Tex Heart Inst J 2001; 28: 312-4.

13. Navid F, Gleason TG. Great vessel and cardiac trauma: diagnostic and management strategies. Semin Thorac Cardiovasc Surg 2008; 20: 31-8.

Funding: None Declared

Conflict of Interest: None Declared

Corresponding Author: Selman Yeniocak

University of Health Sciences, Haseki Training and Research Hospital, Emergency Department, Istanbul, Turkey

E-mail: selmanyeniocakacil@hotmail.com 